\title{
Safety Assessment of Natural Color Foundation for Atopy
}

Min-Jung Kim, ${ }^{1}$ Kun Park ${ }^{2}$, Jeong-Hee Kim ${ }^{3 *}$

${ }^{1}$ Research institute Art Nouveau Co., Ltd, Anseong-si, Gyeonggi-do, Korea

${ }^{2}$ Department of Dermatology, Wonkwang University Hospital, Wonkwang University School of Medicine, Iksan-si, Jeollabuk-do, Korea

${ }^{3}$ Department of Beauty Design, College of Natural Science, Wonkwang University, Iksan-si, Jeollabuk-do, Korea

${ }^{*}$ Correspondence: Jeong-Hee Kim, Department of Beauty Design, Wonkwang University, 460 Iksandae-ro, Iksan-si, Jeollabuk-do 54538, Korea

Tel: $+82-63-850-6898$

Fax: +82638507301

E-mail: jh@wku.ac.kr

Running Title: Safety of Foundation for Atopy 


\title{
Research article
}

\section{아토피용 천연 파운데이션의 안전성 평가}

\author{
김민정, ${ }^{1}$ 박건 $^{2}$, 김정희 ${ }^{3+}$
}

${ }^{1}$ (주) 아르느보 화장품 기업부설 연구소

2 원광대학교, 의과대학 피부과

${ }^{3+}$ 원광대학교 자연과학대학 뷰티디자인학부

Correspondence: 김정희, $\mathrm{PhD}$, 교수

원광대학교 자연과학대학 뷰티디자인학부

우) 54538 전라북도 익산시 익산대로 460

Tel: +82-63-850-6898, Fax: +82-63-850-7301, E-mail: jh@wku.ac.kr

Running Title: 아토피파운데이션 안전성 


\section{Abstract}

Purpose: As a therapeutic makeup product, foundation is used to reduce the anxiety and unease associated with appearance in people with atopic skin problems. The aim of the present study was to prepare and evaluate the safety of natural color foundation for atopy. Methods: Color foundations containing organic kaolin and zinc oxide were prepared. Safety of color foundation was evaluated by MTT cell viability assay (CCD-986sk human skin fibroblast cell line), and human repeat insult patch test for atopic dermatits. Results: Results of the MTT cell viability assay showed that the growth activity of human skin fibroblast cells was over $88 \%$ in all concentrations of the natural color foundations (sample $\mathrm{C}$ and D). Patch test revealed that the natural color foundations were safe. While two cases showed weak positive reactions $(+)$ to sample A and B (general foundation on the market). Conclusion: Natural color foundation with kaolin and zinc oxide was verified safe for atopic dermatitis and it appears to be beneficial for use as a foundation for atopy.

Keywords: Color cosmetics, Cream foundation, Kaolin, Safety, Atopy 


\section{Introduction}

아토피 피부염은 만성적, 재발성의 염증성 피부질환으로 도시화가 진행됨에 따라 유 병률이 급증하고 있다. 아토피 피부염은 피부가 건조해지면서 거칠어지는데 피부의 병변 은 주로 팔다리 등의 피부가 접히는 부위, 얼굴 등에서 찾아볼 수 있다. 얼굴의 경우 홍 조, 피부균열, 모공 각화증으로 태선화 같은 만성 병변이 나타나기도 한다. 심한 경우 뺨 이나 이마, 두피 등에 진물이나 가피(딱지) 형태의 습진 병변 양상이 나타나 피부의 외형 적 변화가 크다. 따라서 아토피 환자의 경우 피부 변형으로 인한 외모 콤플렉스를 수반 하거나 심한 경우 대인기피현상, 우울증을 호소하기도 한다. 따라서 아도피 질환은 장기 간의 치료에도 불구하고, 완치가 어려운 난치성 질환으로 질환정도(severity)에 따라 환 자의 삶의 질에 많은 영향을 미치는 것으로 보고되고 있다(Coghi et al., 2007; Lifschitz, 2015).

아토피 피부염 환자들 중에서도 특히 성인 여성들은 미적 관심 증가와 더불어 사회 활동을 위한 화장의 욕구가 증대되므로 이들을 위한 아토피용 색조화장품 개발이 필요하 다. 특히 색조화장품 중 베이스 메이크업인 파운데이션은 피부의 결점을 보호하는 제품 으로 성인 아토피 여성의 피부 결점을 보완하기 위한 테라피 메이크업에 주요 제품이다 (Jung et al., 2018). 현재 아토피 전용 화장품은 대부분 기초화장품으로 테라피 메이크업 (therapy make-up) 적용을 위한 파운데이션의 개발이 매우 미흡한 실정이다.

카모플라쥬 코스메틱 적용(Sidle \& Decker, 2011)에서 파운데이션은 아토피로 인하 여 변형된 피부색을 커버할 수 있는 필수적인 아이템이다. 따라서 성인 아토피 여성들이 아토피용 파운데이션을 이용하여 테라피 메이크업을 하는 것은 외모에 대한 스트레스와 콤플렉스를 극복할 수 있는 방안이다. 현재 시판되는 파운데이션은 피부에 자극을 유발 할 수 있는(Yanagisawa et al., 2009) 산화철과 titanium dioxide가 다량 함유되어 있으 며, 일반여성들의 파운데이션 사용에 있어서도 피부 부작용이 보고되고 있다(An et al., 2014). 따라서 성인 아토피 여성들은 시판되는 일반 파운데이션의 사용이 불가능하므로, 아토피 피부에 자극적이지 않으며, 피부증상을 커버할 수 있는 아토피용 파운데이션의 개발이 필요하다.

아토피 피부에 적용가능한 파운데이션 개발은 시판 파운데이션 제품에 사용되는 유 기 합성색소와 무기 안료 titanium dioxide, mica, talc 등을 대체할 수 있는 천연색재와 저자극성 원료를 적용하여 파운데이션 제형을 제조하고 아토피 피부를 대상으로 한 안전 성 평가가 수행되어야 한다. 합성색소를 대체할 수 있는 천연색소로서 파운데이션의 혼 
합색상을 발현할 수 있는 색재로는 카올린을 활용할 수 있다. 천연 카올린은 여러 색상 의 산화철을 대체할 수 있는 황색, 적색, 청색의 다양한 색상으로 구성되어 색상 혼합이 용이하다. 또한 titanium dioxide를 대체할 수 있는 zinc oxide는 자외선 차단작용이 있 으며 피부상처치유의 효과가 입증(Abdullah et al., 2019)된 원료이다.

따라서 본 연구에서는 천연 원료인 카올린과 zinc oxide를 파운데이션의 색재와 안 료로 적용하여 아토피용 파운데이션을 제조하고 이에 대한 세포독성 평가와 첩포검사를 수행하여 안전성을 평가하였다.

\section{Methods}

\section{Material \& preparation}

아토피용 파운데이션의 제조를 위해 화장품 색재로서 천연 카올린을 선정하였다. 카 올린은 천연 광물질로 천연 미네랄과 미량요소만으로 조성되어 있다. 주요한 효능으로는 상피박탈제, 궤양, 창상면 또는 습진과 같은 피부질환에 산포해서 피부를 외부 자극으로 부터 보호하고 침출액을 흡착해 건조, 결가(scale)를 촉진하는 흡착제로서 이용하기도 한 다. 비슷하게는 수렴, 소염, 지혈 방부 효과도 볼 수 있으며(Heah et al., 2011), 피부개선 효과도 보고되었다(Choi et al., 2013). 카올린은 화장품원료로서 배합목적에 따라 그 기 능이 매우 다양하게 활용되며 현재까지는 주로 파우더와 팩 제품류의 활용이 일반적이었 다. 파운데이션용 색재로서 활용이 거의 없었으나, 다양한 색상으로 색재를 구성할 수 있 으며, 피부 부작용이 적고 동시에 피부 진정효과를 가지고 있는 장점이 있다. 따라서 파 운데이션에서 사용되는 여러 색상의 산화철을 대체할 수 있다. 사용된 카올린은 브라질 의 BERACA사에서 구입하였다.

아토피용 파운데이션의 제조는 여러 가지 파운데이션 제형 중 크림타입으로 제조하 였다. 크림 파운데이션은 제형 안정도가 우수하며 보습과 커버가 뛰어나므로 테라피 메 이크업을 위한 아토피용 파운데이션 제형으로 가장 적합하다. 또한 제품의 색상은 현재 국내에서 가장 일반적으로 사용되는 21호와 23호에 해당하는 색상을 중심으로 시판 파 운데이션에 해당하는 2개(sample A, B), 카올린 파운데이션 2개(sample C, D) 총 4 개의 파운데이션 시료를 제조하였다. 각각의 시판용 파운데이션과 카올린 파운데이션의 제조 에 사용되는 원료 및 기준량은 Table1, Table 2와 같다. 
시판용 파운데이션과 아토피용 파운데이션의 제조 과정은 동일하며 색재에 해당하는 주요 원료의 적용이 다르다. 먼저 오일에 해당하는 원료를 모두 측량하여 비커에 담은 뒤 $80^{\circ} \mathrm{C}$ 로 가열한다. 이 후 유화제, 왁스, 방부제, 실리콘의 혼합액을 오일 상에 넣어준 다. 이 때 아지믹서(Hei-TORQUE value 100; heidolph Instruments GmbH \& CO., Germany)는 $1500 \mathrm{rpm}$ 으로 $80^{\circ} \mathrm{C}$ 에서 약 $20 \mathrm{~min}$ 혼합한다. 모든 원료가 용해되었을 때 각 시료의 해당 색재 원료를 넣어 분산시킨다. 분산은 아지믹서 $1500 \mathrm{rpm}$ 으로 하였다. 이 후 각각의 시료를 여과한 뒤 냉각시켜준다(Figure 1).

\section{MTT cell viability assay}

CCD-986sk cell line (인체섬유모세포, human fibroblast skin cell KCLB-21947)은 한국세포 주은행(KCLB, Seoul, Korea)에서 분양 받았다.

CCD-986sk cell line은 10\% fetal bovine serum (FBS; Hyclone, USA), 0.22\% sodium bicarbonate (Sigma-Aldrich, USA)가 함유된 Dulbecco's modified Eagle's medium (DMEM; GIBCO, USA)에 $100 \mu \mathrm{g} / \mathrm{mL}$ streptomycin을 혼합한 배지를 사용하여 $37^{\circ} \mathrm{C}, 5 \%$ $\mathrm{CO}_{2}$ incubator에서 배양하였다. 제조된 파운데이션이 세포 사멸에 미치는 영향을 알아보 기 위해 세포 증식과 생존율을 측정하는 발색 분석법인 Cell Counting Kit (CCK)-8을 시 행하며, 96-well plate에 각 well 당 human fibroblast cell을 $5 \times 10^{3}$ 개로 분주하였다. 대조군과 시험시료를 $\mathrm{DMEM}$ 배지에 희석시켜 원심분리한 후 상층 액을 수집하여 실험에 사용하였다. 희석한 시료는 3 개의 well에 각각 $200 \mu \mathrm{L}$ 씩을 처리하여 $48 \mathrm{~h}$ 동안 세포 배 양기에서 배양한 후, 상층액을 제거하여 PBS 용액으로 2번 세척하였다. CCK-8 $20 \mu \mathrm{L}$ 씩 첨가하여 세포 배양기에서 1-4 h 동안 배양 후 Microplate reader (SLT, Austria)에서 $450 \mathrm{~nm}$ 의 파장으로 흡광도를 측정하며, 각 실험은 독립적으로 3 회 반복 실행하여 평균 치와 표준편차를 구하였다.

\section{Participants}

연구의 지원자는 아토피 피부염 진단 경험이 있는 20 대 여성 30 명을 선정하였다. 연구 기간은 2017 년 2 월 1 일부터 28 일까지 한 달 동안 진행되었다. 피험자들은 아토피 피부염의 경도와 중등도 이하에 해당하는 여성들로 Table 3 과 같은 평가기준에 준하여 선정되었고, 진단결과 고도에 해당하는 지원자는 첩포시험에서 제외하였다. 제조된 파운데이션 시료에 대한 임상시험을 위해 원광대학교 생명윤리위원회(Institution 
Review Board, IRB) 심사를 실시하고 연구 수행의 승인을 받았다(연구승인번호: WKIRB-201611-BM-060). IRB 승인 후 연구지원자들에게 연구의 목적과 과정을 충분히 설명한 뒤 시험을 실행하였다.

\section{Human repeat insult patch test}

제조된 파운데이션 시료의 인체 피부 자극성을 평가하기 위해 연구지원자를 대상으 로 첩포시험을 실시하였다. 시험 부위는 척추 기립근을 축으로 양쪽 견갑골 사이이며, 시 험 부위를 $70 \%$ 에탄올로 닦는다. 각각의 시료를 $25 \mathrm{mg}$ 씩 IQ Ultra chamber에 적용하여 시험 부위에 고정시켰다. $48 \mathrm{~h}$ 밀폐시킨 후 첩포를 제거하고 $45 \mathrm{~min}$ 후의 반응을 확인하 였다. 첩포시험 기간은 일주일에 1 회씩 반복적으로 4 주 동안 실험을 진행하였다. 결과의 판독은 국제 접촉 피부염 연구위원회(International Contact Dermatitis Research Group, $\mathrm{ICDRG)}$ 의 판정 기준에 따라 첩포 부위의 홍반 발생 유무를 평가하였다.

\section{Statistical analysis}

자료분석은 SPSS for Windows version 24.0 program을 이용하여 실험결과의 평균 과 표준편차를 구하고, 결과의 비교를 위해 t-test와 ANOVA를 실시하였다.

\section{Results and Discussion}

\section{MTT cell viability assay}

시판 파운데이션의 21호와 23호에 해당하는 sample A와 $\mathrm{B}$, 아토피용 파운데이션의 21 호와 23호에 해당하는 sample C와 D의 4가지 시료에 대하여 제품의 각 농도 별 $(5,000$ ppm, $10,000 \mathrm{ppm}, 15,000 \mathrm{ppm}, 20,000 \mathrm{ppm}$ ) 세포 생존율을 측정하였다. 각 시료 별 세 포생존율을 비교한 결과는 Figure 2와 같다. Sample A의 세포생존율은 $5,000 \mathrm{ppm}$, $10,000 \mathrm{ppm}$ 에서 $80 \%$ 이상의 생존율을 보이며, $15,000 \mathrm{ppm}$ 에서는 $80 \%$ 이하의 생존율을 보였다. Sample B는 5,000 ppm에서만 $80 \%$ 이상의 생존율을 보였으며, $10,000 \mathrm{ppm}$ 에 서는 $80 \%$ 이하의 세포생존율을 보였다. 또한 $20,000 \mathrm{ppm}$ 에서는 $70 \%$ 이하의 세포생존율 을 보여 4가지 sample 중 가장 낮은 수치를 보였다. Sample B의 세포생존율은 5,000 $\mathrm{ppm}$ 에서 $80.35 \%$ 였으며 $10,000 \mathrm{ppm}$ 에서 $77.76 \%, 15,000 \mathrm{ppm}$ 은 $71.06 \%$ 로 $70 \%$ 이상 
의 세포생존율이 측정되었다. 그러나 $20,000 \mathrm{ppm}$ 에서 $69.41 \%$ 로 $70 \%$ 이하의 세포생존 율이 나타났다.

특히 각 시료 내에서 농도 별 세포생존율 변화를 비교하였을 때(t-test), sample A와 sample B에서 5,000 ppm과 20,000 ppm의 농도에서 유의한 차이가 나타났다( $p<0.001)$. Sample A와 B는 농도가 높아질수록 세포생존율이 많이 떨어지며 동일 시료내에서의 유 의한 차이가 나타났으나, 이와 반대로 sample C와 $\mathrm{D}$ 는 시료의 농도가 높아져도 세포생 존율의 변화 폭이 작은 것을 알 수 있었다.

Sample A와 B의 세포생존율이 C와 $\mathrm{D}$ 보다 낮은 결과를 살펴보면 sample $\mathrm{A}$ 와 $\mathrm{B}$ 시 료의 원료 중 산화철과 티타늄디옥사이드와 Sample $\mathrm{C}$ 와 $\mathrm{D}$ 의 원료 중 카올린과 징크옥 사이드의 차이가 생존율에 영향을 미치는 것으로 추측된다. 물론 산화철에 해당하는 iron oxide red, hydrated ferric oxide, black iron oxide는 식품의약품안전처 고시 「화장품법」 제 8조 제 2항에 따라 화장품 색소로 규정되어 안전성이 입증된 원료이다. 또한 Zhang \& Monteiro-Riviere (2018), Zeng et al. (2018)의 선행연구에서도 titanium dioxide의 세포독성 평가에서 particle size가 큰 경우 세포독성이 없는 것을 보고하고 있다. Sample A와 B의 세포생존율측정 결과 $20,000 \mathrm{ppm}$ 의 농도에서 $70 \%$ 정도로 세포독성에 대한 안정성이 입증되었다. 이는 천연 원료인 카올린과 징크옥사이드와 비교하였을 때는 skin fibroblast cell의 생존율이 낮게 나타났지만, sample A와 B의 시료가 건강한 피부를 대상으로 한 화장품 적용에는 문제가 없음을 확인하였다.

\section{Human repeat insult patch test}

제조된 파운데이션 sample $\mathrm{A}, \mathrm{B}$ 와 $\mathrm{C}, \mathrm{D}$ 의 세포독성에 대한 안전성을 확인하였다 하 더라도, 아토피 피부 적용에 대한 in vitro 측면에서의 시료에 직접적 사용에 대한 첩포 검사 평가가 필요하다. 따라서 아토피의 경도에서 중도에 해당하는 지원자 30 명을 대상 으로 각 시료에 대한 4 주간의 반복폐쇄 첩포시험을 실시하였고, 그 결과를 ICDRG의 기 준에 따라 진단하였다(Table 4).

Sample A 와 B 의 시료는 3 주차에 지원자 중 2 명 $(6.67 \%)$ 이 약간의 홍반과 구진의 형태를 보이는 week positive reaction (+)으로 진단되었다. 그러나 sample C 와 D 의 시료는 4 주간 어떠한 부작용도 나타나지 않았다.

일반적인 화장품의 피부자극에 대한 첩포시험의 선행연구 결과를 살펴보면 An et al. (2014)는 우리나라 여성 7,440 명을 대상으로 화장품의 피부 자극에 대한 첩포시험을 실시하였고 피험자의 $4.2 \%$ 가 파운데이션 제품에 의한 피부 부작용이 발생한 것으로 
보고하였다. 이 연구의 첩포시험 결과에서는 아토피 피부에 해당하는 여성을 대상으로 시판되는 파운데이션 sample $\mathrm{A}$ 와 $\mathrm{B}$ 의 시료를 적용한 결과 $6.67 \%$ 의 피부 부작용이 발생하였고, 이는 일반 여성을 대상으로 한 시험결과보다 부작용이 더 높게 나타났다. 그러나 sample C 와 D 에서는 부작용이 나타나지 않았는데 그 이유는 일반 파운데이션에 사용되는 색재(산화철과 티타늄디옥사이드)로 유추된다.

일반적으로 아토피 환자의 경우 화학제품 및 화장품의 지속적인 사용은 피부부작용을 초래하는 것으로 보고하고 있다(Puangpet et al. 2013). 현재까지의 선행연구들은 titaium 을 non-allergernic 물질로 간주하였으나 최근에는 이러한 신뢰가 잠식되고 있으며 titanium allergy 에 대한 몇몇 연구들이 보고되고 있다. de Graaf et al. (2018)의 연구에서도 titimium 에 대한 첩포검사 결과 전체 대상자 458 명 중 1 positive result 를 $5.68 \%$ ( $\mathrm{N}=26)$ 로, 티타늄디옥사이드의 경우 329 명 중 $0.91 \%(\mathrm{~N}=3)$ 로 보고하였다. Yanagisawa et al. (2009)의 연구에 따르면 아토피 환자에 대한 항염증 효과를 분석하기 위해 titanium dioxide nanoparticle 을 아토피피부염에 적용한 결과 알레르기를 일으키는 것으로 보고하고 있다. 또한 van Ketel \& Liem (1981)의 연구에 따르면 cosmetic 에 포함되는 니켈은 발암성 및 유전 독성으로 인하여 인체에 유해하다고 보고하고 있다.

이와 같이 일반 파운데이션에 사용되는 색재 중 티타늄디옥사이드와 산화철의 경우 피부부작용에 대한 문제가 제기되고 있음을 선행연구를 통해 분석하였고 또한 이 연구의 첩포시험 결과와 일치함을 알 수 있다.

그러나 천연색재인 카올린과 징크옥사이드를 사용해 제조한 파운데이션 sample C 와 $\mathrm{D}$ 의 경우 아토피 피부에 부작용이 없었다. 결과적으로 아토피 피부에 시판 파운데이션을 적용할 경우 일반 피부보다 부작용이 더 높게 나타났으며 그 원인은 티타늄디옥사이드와 산화철에 대한 부작용으로 유추할 수 있다. 또한 이를 보완하는 원료로서 징크옥사이드와 카올린을 대체하였을 때 피부적용에 대한 안전성을 확인할 수 있었다.

\section{Conclusion}

아토피에 해당되는 성인 여성은 시판되는 파운데이션 제품을 사용하는 것이 불가능 한 실정이다. 이에 따라 아토피 피부에 적용가능한 파운데이션을 개발하는 것이 연구의 목적이었다. 
따라서 시판 파운데이션의 원료 중 피부 부작용을 일으킬 수 있는 주요 원료인 티타늄디옥사이드와 산화철을 카올린과 징크옥사이드로 대체하여 천연색조 파운데이션을 제조하고, 이에 대한 안전성을 평가하였다. 파운데이션 시료에 대한 세포독성의 경우 모든 시료에서 안전성이 확보되었지만 실제 아토피 경도 및 중증도에 해당하는 30 명의 피험자를 대상으로 4 주간 반복폐쇄 첩포시험을 시행한 결과, 시판 파운데이션에 해당하는 sample $\mathrm{A}$ 와 $\mathrm{B}$ 의 경우 부작용이 나타났다. 그러나 천연색조 파운데이션의 경우 반복적인 피부 적용에도 어떠한 부작용도 나타나지 않아 화장품으로서 제품 안전성을 확보하였다. 제조된 천연색조 파운데이션은 아토피용 파운데이션으로서 테라피 메이크업 제품으로서 활용이 가능하며 이와 더불어 카올린의 경우, 현재까지는 파우더와 팩에 활용되는 화장품 원료로서의 제한적 사용보다는 색재로서 아이새도, 블러셔와 같은 여러 색조화장품 아이템에 적용하여 다양한 활용을 기대해 볼 수 있는 원료로 후속연구에 대한 필요성을 인식하였다. 


\section{References}

Abdullah BJ, Atasoy N, Omer AK. Evaluate the effects of platelet rich plasma (PRP) and zinc oxide ointment on skin wound healing. Annals of Medicine and Surgery, 37: 30-37, 2019.

An SM, Ham H, Choi EJ, Shin MK, An SS, Kim HO, Koh JS. Primary irritation index and safety zone of cosmetics: retrospective analysis of skin patch tests in 7440 Korean women during 12 years. International Journal of Cosmetic Science, 36: 62-67, 2014.

Coghi S, Bortoletto MC, Sampaio SAP, de Andrade HF, Aoki V. Quality of life is severely compromised in adult patients with atopic dermatitis in Brazil, especially due to mental components. Clinics, 62: 235-242, 2007.

Choi SJ, Baeck SW, Choi MH, Jo A, Jang HH, Oh CR , Ahn KJ, An IS, An S, Oh JS. Effects of the face pack containing kaolin, adenosine and plant extracts on the skin improvement. Asian Journal of Beauty and Cosmetology, 11: 993-1000, 2013.

de Graaf NPJ, Feilzer AJ, Kleverlaan CJ, Bontkes H, Gibbs S, Rustemeyer T. A retrospective study on titanium sensitivity: patch test materials and manifestations. Contact Dematitis, 79: 85-90, 2018.

Heah CY, Kamarudin H, Mustafa Al Bakri AM, Binhussain M, Luqman M, Khairul Nizar I, Ruzaidi CM, Liew YM. Effect of curing profile on kaolin-based geopolymers. Physics Procedia, 22: 305-311, 2011.

Jung I, An IS, An S. Color comparison between Korean and foreignmade base makeup products. Asian Journal of Beauty and Cosmetology, 16: 277286, 2018.

Lifschitz C. The impact of atopic dermatitis on quality of life. Annals of Nutrition \& Metabolism, 66: 34-40, 2015.

Puangpet P, Lai-Cheong J, McFadden JP. Chemical atopy. Contact Dermatitis, 68: 208-213, 2013.

Sidle DM, Decker JR. Use of makeup, hairstyles, glasses, and prosthetics as adjuncts to scar camouflage. Facial Plastic Surgery Clinics of North America, 19: 481-489, 2011. 
van Ketel WG, Liem DH. Eyelid dermatitis from nickel contaminated cosmetics. Conta ct Dematitis, 7: 217, 1981.

Yanagisawa R, Takano H, Inoue K, Koike E, Sadakane K, Ichinose T. Titanium dioxid e nanoparticles aggravate atopic dermatitislike skin lesions in NC/Nga mice. Experimental Biology and Medicine, 234: 314322, 2009.

Zeng C, Feng Y, Wang W, Zhou F, Liao F, Liu Y, Feng S. The sizedependent apoptotic effect of titanium dioxide nanoparticles on endothelial cells by the intracellular pathway. Environmental Toxicology, 33: 1221-1228, 2018.

Zhang LW, Monteiro-Riviere NA. Toxicity assessments of six titanium dioxide nanoparticles in human epidermal keratinocytes. Cutaneous and Ocular Toxicology, 38: 66-80, 2018. 


\title{
국문초록
}

\section{아토피용 천연 파운데이션의 안전성 평가}

\author{
김민정1, 박건2, 김정희 ${ }^{3 *}$
}

1(주)아르느보 화장품 기업부설 연구소, 경기도 안산시, 한국

2원광대학교 의과대학 피부과, 전라북도 익산시, 한국

${ }^{3}$ 원광대학교 자연과학대학 뷰티디자인학부, 전라북도 익산시, 한국

목적: 아토피 증상을 커버하기 위한 색조화장품 중 파운데이션의 개발은 미비한 실정이 다. 따라서 아토피 피부에 적용할 수 있는 천연색조화장품을 제조하고 이에 대한 안전성 을 평가하고자 하였다. 방법: 시판 파운데이션의 색재인 티타늄디옥사이드와 산화철을 각 각 징크옥사이드와 카올린으로 대체하여 아토피용 천연 파운데이션을 제조하였다. 제조 한 파운데이션 제품의 안전성 평가를 위해 피부섬유아세포를 대상으로 MTT cell viability assay를 실시하였다. 또한 실제적 적용에 대한 평가를 위해 경도 및 중등도에 해당하는 아토피 여성 30 명을 대상으로 반복폐쇄첩포시험을 4 주간 시행하였다. 결과: MTT cell viability assay 결과, 천연 파운데이션의 경우 모든 농도 $(5,000 \mathrm{ppm}, 10,000$ $\mathrm{ppm}, 15,000 \mathrm{ppm}, 20,000 \mathrm{ppm}$ )에서 $88 \%$ 이상의 세포생존율이 나타나 안전성을 확인하 였다. 시판 파운데이션 시료의 경우에서 가장 높은 농도에서 $69 \%$ 이상의 세포생존율을 보여 안전성이 나타났다. 첩포시험의 경우 시판파운데이션 시료에서는 $6.67 \%$ 의 week positive reactions (+)이 나타나 피부부작용을 초래하는 것을 확인하였다. 그러나 천연 파운데이션 시료에서는 어떠한 피부부작용도 나타나지 않아 실제 피부 적용에 안전한 것 으로 확인되었다. 결론: 결과적으로 카올린과 징크옥사이드를 이용하여 제조한 천연파운 데이션은 아토피용 파운데이션으로서 안전성을 확인하였다.

핵심어: 색조 화장품, 크림 파운데이션, 카올린, 안전성, 아토피 
참고문헌

최성진, 백승우, 최민화, 조아령, 장현희, 오창록, 안규중, 안인숙, 안성관, 오정숙. 카올린, 아데노신 및 식물복합추출물이 함유된 안면팩의 패부개선 효과. 아시안뷰티화장품학술지, 11: 993-1000, 2013.

정인, 안인숙, 안성관. 국가별 베이스 메이크업 제품의 색상 비교. 아시안뷰티화장품학술지, 16 : 277-286, 2018. 


\section{中文摘要}

\section{天然粉底用于特应性皮炎的安全性评价}

金忮正 ${ }^{1}$, 朴健 $^{2}$ ，金柾希 ${ }^{3 *}$

1 (株) Art Nouveau 化妆品企业附属研究所, 京畿道安城市, 韩国

2 圆光大学医科大学皮肤科, 全罗北道益山市, 韩国

3 圆光大学自然大学美容设计学科, 全罗北道益山市, 韩国

目的: 作为治疗性化妆品, 粉底用于减少患有特应性皮肤问题的人的焦虑和与外表相 关的不安。本研究的目的是准备和评估特应性天然彩色粉底的安全性。方法: 制备含 有机高岭土和氧化锌的彩色粉底。通过MTT细胞活力测定（CCD-986sk人皮肤成纤维细 胞系）和特应性皮炎的人重复损伤斑贴试验评价了色基础的安全性。结果：MTT细胞活 力测定的结果显示, 在所有浓度的天然颜色基础（样品C和D）中, 人皮肤成纤维细胞 的生长活性超过 $88 \%$ 。斑贴试验显示, 天然彩色粉底中, 没有观察到皮肤副作用, 并 且确认其对于实际皮肤应用是安全的。虽然两个案例显示对样本 $A$ 和 $B$ （市场上的一般 彩色粉底) 的弱阳性反应 (+)。结论: 高岭土和氧化锌的天然色基被证实对特应性皮 炎是安全的，并且它似乎有利于作为特应性的基础粉底。

关键词: 彩妆, 粉底霜, 高岭土, 安全, 特应性 


\section{Tables}

Table 1. Ingredients of general foundations

(Unit: g)

\begin{tabular}{llrr}
\hline Phase & Sample A & Sample B \\
& Polyethylene & 2.000 & 2.000 \\
Ozokerite & 2.000 & 2.000 \\
Microcrystalline Wax & 2.500 & 2.500 \\
Beeswax & 1.500 & 1.500 \\
Ceresin & 1.000 & 1.000 \\
Sorbitan Olivate & 3.000 & 3.000 \\
Diisostearyl Malate & 5.000 & 5.000 \\
Dipentaerythrityl Hexahydroxystearate/Hexastearate & 3.000 & 3.000 \\
/Hearosinate & 7.000 & 7.000 \\
Polybutene & 1.045 & 4.045 \\
Mineral Oil & 5.000 & 5.000 \\
Caprylic/Capric Triglyceride & 1.500 & 1.500 \\
Sorbitan Sesquioleate & 0.500 & 0.500 \\
VP/Hexadecene Copolymer & 0.150 & 0.150 \\
Methylparaben & 0.050 & 0.050 \\
Propylparaben & 3.336 & 3.336 \\
Phenyl Trimethicone & 16.930 & 15.780 \\
Dimethicone & 0.834 & 0.834 \\
Lauryl PEG/PPG-18/18 Methicone & 7.000 & 7.000 \\
Cyclopentasiloxane & 3.000 & 3.000 \\
Zinc Stearate & 5.000 & 5.000 \\
Polymethyl Methacrylate & 0.880 & 0.880 \\
Silica & 0.045 & 0.045 \\
Isopropylmyristate & 0.030 & 0.030 \\
Dimethicone & 0.350 & 0.400 \\
Iron Oxide Red (CI 77491) & 5.100 & 3.100 \\
Hydrated Ferric Oxide (CI 77492) & 0.250 & 0.350 \\
Black Iron Oxide (CI 77499) & 22.000 & 22.000 \\
Titanium Dioxide & 100.000 & 100.000 \\
\hline
\end{tabular}


Table 2. Ingredients of kaolin foundations for atopy

(Unit: g)

\begin{tabular}{|c|c|c|c|}
\hline Phase & Ingredients & Sample C & Sample D \\
\hline \multirow{24}{*}{ Base } & Polyethylene & 2.000 & 2.000 \\
\hline & Ozokerite & 2.000 & 2.000 \\
\hline & Microcrystalline Wax & 2.500 & 2.500 \\
\hline & Beeswax & 1.500 & 1.500 \\
\hline & Ceresin & 1.000 & 1.000 \\
\hline & Sorbitan Olivate & 3.000 & 3.000 \\
\hline & Diisostearyl Malate & 5.000 & 5.000 \\
\hline & $\begin{array}{l}\text { Dipentaerythrityl Hexahydroxystearate/Hexastearate } \\
\text { /Hearosinate }\end{array}$ & 3.000 & 3.000 \\
\hline & Polybutene & 7.000 & 7.000 \\
\hline & Mineral Oil & 4.045 & 4.045 \\
\hline & Oenothera Beiennis(Evening Primrose) Oil & 1.000 & 1.000 \\
\hline & Caprylic/Capric Triglyceride & 5.000 & 5.000 \\
\hline & Sorbitan Sesquioleate & 1.500 & 1.500 \\
\hline & VP/Hexadecene Copolymer & 0.500 & 0.500 \\
\hline & 1,2-Hexandiol & 0.200 & 0.200 \\
\hline & Phenyl Trimethicone & 3.336 & 3.336 \\
\hline & Dimethicone & 12.630 & 11.430 \\
\hline & Lauryl PEG/PPG-18/18 Methicone & 0.834 & 0.834 \\
\hline & Cyclopentasiloxane & 7.000 & 7.000 \\
\hline & Zinc Stearate & 3.000 & 3.000 \\
\hline & Polymethyl Methacrylate & 5.000 & 5.000 \\
\hline & Silica & 0.880 & 0.880 \\
\hline & Isopropylmyristate & 0.045 & 0.045 \\
\hline & Dimethicone & 0.030 & 0.030 \\
\hline \multirow{5}{*}{ Colorant } & Kaolin Red & 0.700 & 0.800 \\
\hline & Kaolin Yellow & 4.500 & 5.400 \\
\hline & Kaolin Black & 0.800 & 1.000 \\
\hline & Zinc Oxide & 22.000 & 22.000 \\
\hline & Total & 100.000 & 100.000 \\
\hline
\end{tabular}


Table 3. Severity of atopic dermatitis

Division Severity of atopic dermatitis

Mild Atopic dermatitis less than $10 \%$ of total body surface area

Moderate Atopic dermatitis accounts for $10 \%$ to $30 \%$ of the total body surface area

Severe Atopic dermatitis accounts for more than $40 \%$ of the total body surface area 
Table 4. Results of human repeat insult patch test

$(\mathrm{N}=30)$

\begin{tabular}{|c|c|c|c|c|c|c|c|}
\hline & Sample & - & $+/-$ & + & ++ & +++ & $\begin{array}{c}\text { Positive rate } \\
(\%)\end{array}$ \\
\hline \multirow{4}{*}{1 week } & Sample A & 30 & - & - & - & - & 0 \\
\hline & Sample B & 30 & - & - & - & - & 0 \\
\hline & Sample C & 30 & - & - & - & - & 0 \\
\hline & Sample D & 30 & - & - & - & - & 0 \\
\hline \multirow{4}{*}{2 weeks } & Sample A & 30 & - & - & - & - & 0 \\
\hline & Sample B & 30 & - & - & - & - & 0 \\
\hline & Sample C & 30 & - & - & - & - & 0 \\
\hline & Sample D & 30 & - & - & - & - & 0 \\
\hline \multirow{4}{*}{3 weeks } & Sample A & 28 & - & 2 & - & - & $6.67 \%$ \\
\hline & Sample B & 28 & - & 2 & - & - & $6.67 \%$ \\
\hline & Sample C & 30 & - & - & - & - & 0 \\
\hline & Sample D & 30 & - & - & - & - & 0 \\
\hline \multirow{4}{*}{4 weeks } & Sample A & 28 & - & & - & - & 0 \\
\hline & Sample B & 28 & - & - & - & - & 0 \\
\hline & Sample C & 30 & - & - & - & - & 0 \\
\hline & Sample D & 30 & - & - & - & - & 0 \\
\hline
\end{tabular}

- , no irritant reaction (discrete patchy erythema without infiltration).

$-/+$, doubtful reaction (faint macular, No infiltration, Homogenous erythema).

+ , weak positive reaction (erythema, Induration, Papules).

++ , strong positive reaction (erythema, Induration, Papules, Discrete vesicles).

+++ , extreme positive reaction (coalescing vesicles, Bullous or ulcerative reaction). 


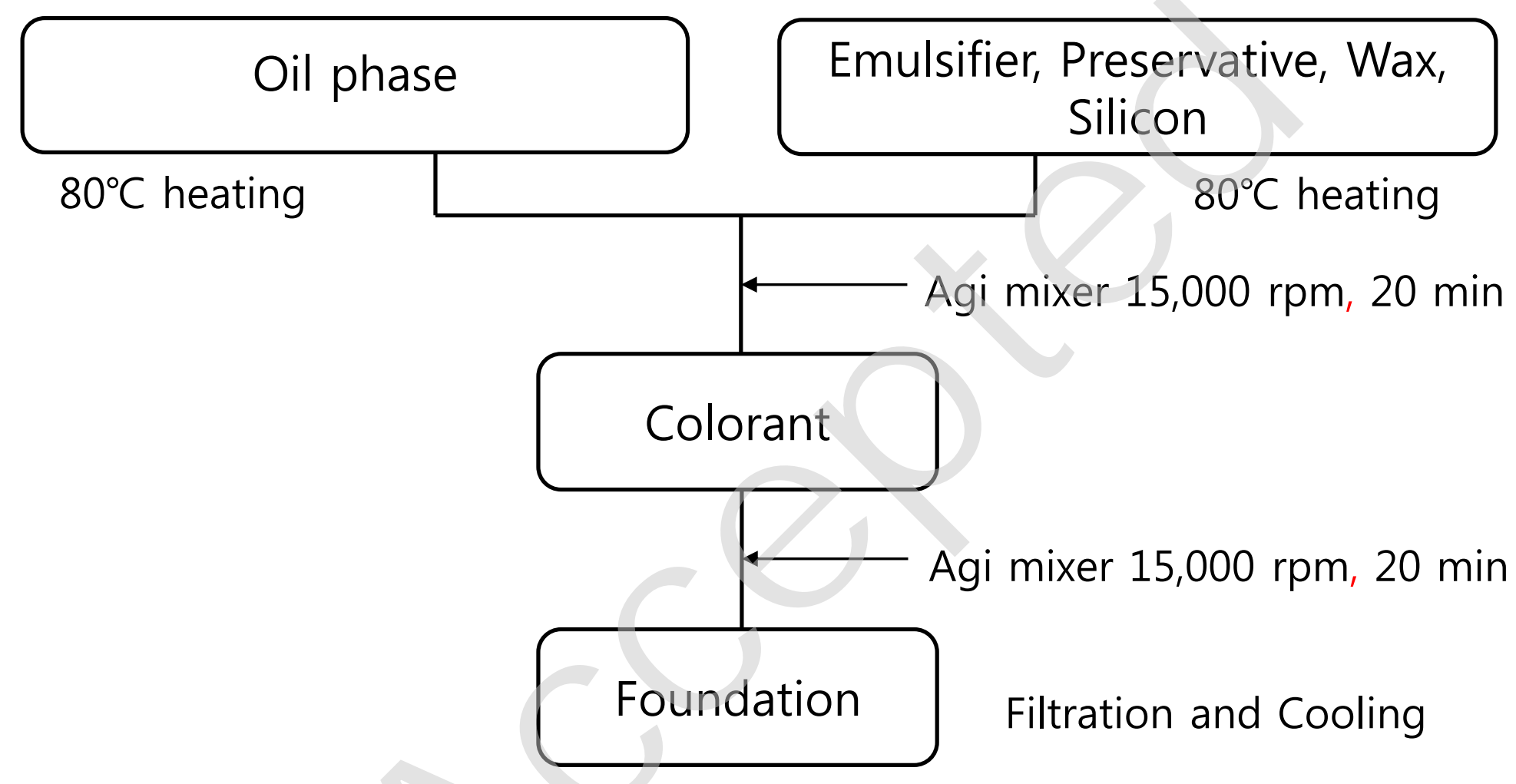

Figure 1. Foundation manufacturing process. 


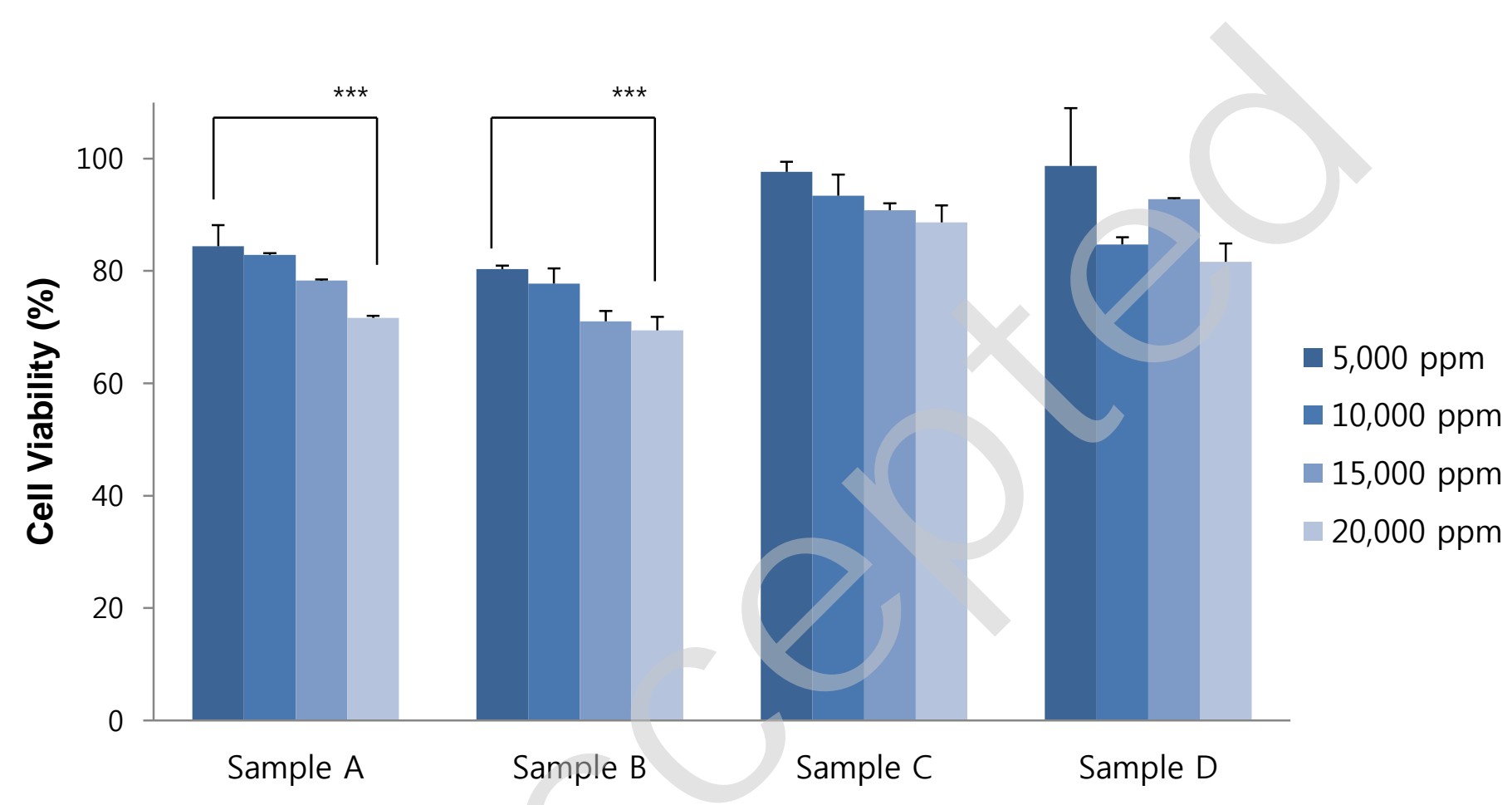

Figure 2. Cytotoxicity of foundations in skin fibroblast cell.

CCD-986sk cells were plated in four foundations with concentrations of 5,000-20,000 ppm for 3 days and measured using MTT assay, as described in the material and methods. Data were analyzed using the paired $t$-test. Statistical significance was found at ${ }^{*} p<0.05,{ }^{* *} p<0.01,{ }^{* * *} p<0.001$. Sample A, No. 21 foundation on the market; Sample B, No. 23 foundation on the market; Sample C, No. 21 foundation containing kaolin and zinc oxide; Sample D, No. 23 foundation containing kaolin and zinc oxide; MTT, 3-(4,5-Dimethylthiazol-2-yl)-2,5-diphenyltetrazolium bromide. 